\title{
PERBEDAAN KESIAPAN UNTUK BERUBAH KARYAWAN DIREKTORAT PRODUKSI PT. PETROKIMIA GRESIK DITINJAU DARI USIA
}

\author{
Agung Puji Astono ${ }^{1}$, Idha Rahayuningsih ${ }^{2}$ \\ Universitas Muhammadiyah Gresik
}

\begin{abstract}
Abstrak
Penelitian ini bertujuan untuk menganalisis perbedaan kesiapan untuk berubah karyawan ditinjau dari usia. Populasi yang digunakan adalah 948 karyawan direktorat produksi PT.. PETROKIMIAdengan teknik sampel yang digunakan adalah sampling proportional dengan jumlah sampel 274 karyawan berdasarkan tabel Kritjie.Teknik analisis adalah Kruskal Wallis dan uji Mann Whitney U.Penelitian ini menggunakan pendekatan penelitian kuantitatif dengan teknik analisis komparasi. Hasil uji hipotesis Kruskall Wallis $=0,000(\mathrm{p}<0,05)$. Hal ini menunjukkan ada perbedaan kesiapan untuk berubah karyawan ditinjau dari usia. Hasil uji Mann Whitney $U$ menunjukkan mean rank yang berbeda, kelompok usia 17-22 tahun $=40,26$; kelompok usia 23-28=115,00; kelompok usia 29-33 tahun $=221,39$ dan kelompok usia 45-56 tahun $=186,72$. Berdasarkan hasil tersebut dapat disimpulkan bahwa kesiapan untuk berubah yang paling rendah terdapat pada kelompok usia 17-22 tahun,sedangkan kesiapan untuk berubah yang paling tinggi terdapat pada kelompok usia 29-33 tahun.
\end{abstract}

Kata kunci : Kesiapan untuk berubah, Tingkat Usia, Karyawan

\begin{abstract}
This study aims to analyze differences in readiness to change employees in terms of age. The population used is 948 employees of directorate of production of PT. PETROKIMIA with sample technique used is proportional sampling with total sample 274 employees based on Kritjie table. The analysis technique is Kruskal Wallis and Mann Whitney U test. This research uses quantitative research approach with comparative analysis technique. Result of hypothesis test Kruskall Wallis $=0,000(p<0,05)$.This shows there is a difference in readiness to change employees in terms of age. The results of the Mann Whitney $U$ test showed different mean ranks, the age group 17-22 years $=40.26$; age group 23-28 = 115.00; age group 29-33 years $=221,39$ and age group 45-56 years $=$ 186,72.Based on these results it can be concluded that the lowest readiness to change is in the age group 17-22 years, while the highest readiness to change is in the age group 29-33 years.
\end{abstract}

Keywords: Readiness to Change, Age Level, Employee

$\overline{1}$ Email : agungpuji.psi@gmail.com

Fakultas Psikologi Universitas Muhammadiyah Gresik

Jalan Sumatra No.101 Gresik Kota Baru (GKB) Gresik 


\section{Pendahuluan}

Sejak berdirinya tahun 1972 sampai saat ini, PT. Petrokimia Gresik telah menjadi pabrik pupuk terlengkap dan terbesar di Indonesia. Kegiatan riset dan inovasi yang terus dilakukan, PT. Petrokimia Gresik menjadi faktor penting bagi pembangunan pertanian melalui penyediaan pupuk yang berkualitas, beragam, dan mampu mencukupi kebutuhan pupuk secara nasional. PT. Petrokimia Gresik adalah salah satu produsen pupuk yang mendapat amanah dari pemerintah untuk ikut memenuhi kebutuhan pupuk nasional dalam rangka mewujudkan kedaulatan dan kemandirian pangan nasional. PT. Petrokimia Gresik memiliki target-target yang harus dicapai setiap tahunnya. Sebagaimana yang tampak pada tabel 1., terdapat 5 produksi pupuk yang menjadi target perusahaan, yaitu urea, SP-36, NPK, ZK dan ZA.

\section{Tabel 1. Target Produksi}

\begin{tabular}{|c|c|c|c|c|}
\hline \multicolumn{5}{|c|}{ TARGET PRODUKSI PUPUK } \\
\hline No & Produksi Produk & RKAP 2018 & Real 2017 & $\begin{array}{c}\text { Presentase } \\
\text { (RKAP } 2018 \text { terhadap real } 2011 \text { ) }\end{array}$ \\
\hline \multirow{2}{*}{1} & \multirow{2}{*}{ Urea } & (Urea I) 357.500 & 460.015 & \multirow{2}{*}{ ^ $30,43 \%$} \\
\hline & & (Urea II) 242.500 & & \\
\hline 2 & SP-36 & 500.000 & 460.015 & ^ $8,69 \%$ \\
\hline 3 & NPK & 2.600 .000 & 2.812 .932 & $-7,56 \%$ \\
\hline 4 & ZK & 16.000 & 15.184 & $5,37 \%$ \\
\hline \multirow[t]{2}{*}{5} & ZA & 790.000 & 798.782 & $-1,09 \%$ \\
\hline & Total & 4.506 .000 & 4.546 .928 & $-0,9 \%$ \\
\hline
\end{tabular}

Sumber : PT. Petrokimia Gresik (2018)

Selain berkaitan dengan masalah target produksi, terdapat pula beberapa tantangan dan masalah yang dihadapi oleh perusahaan pada tahun 2018. Beberapa tantangan yang dihadapi PT. Petrokimia, antara lain :

a. Pasokan gas bumi.Kepastian pasokan gas bumi eksisting akan segera berakhir pada tahun 2020, sedangkan pasokan gas bumi baru hanya dapat dipastikan selama 10 tahun sejak 2019. Harga gas bumi yang cukup tinggi menyebabkan Harga Pokok Penjualan (HPP) pupuk kurang kompetitif.

b. Tingginya impor bahan baku, Lebih dari $70 \%$ bahan baku berasal dari impor dan transaksi menggunakan mata uang dollar.Pemasok bahan baku dunia terbatas pada negara tertentu, sehingga berpotensi menyebabkan fluktuatifnya harga bahan baku.

c. Persaingan produk semakin ketat.Semakin banyak pemain baik lokal maupun impor di sektor pupuk dengan harga yang kompetitif. 
Selain tantangan beberapa permasalahan yang dihadapi perusahaan, diantaranya :

a. Demografis karyawan $\pm 47,5 \%$ karyawan saat ini berusia di atas 51 tahun. Berdasarkan data pada Gambar1. menunjukkan bahwa karyawan yang berusia diantara 21-25 tahun berjumlah 754 karyawan, sedangkan karyawan yang berusia 26-30 tahun ada 675. Lalu, yang berusia 31-35 tahun ada 182 karyawan. Karyawan yang berusia antara 36-40 tahun hanya ada 22 karyawan. Begitu pula yang berusia 41-45 tahun juga hanya ada 6 karyawan, jumlah ini bisa dikatakan yang paling sedikit diantara tingkat usia yang lain. Lalu, pada tingkatan usia 46-50 tahun terdapat 60 karyawan dan tingkatan yang berada di atas usia 51 tahun terdapat 1.539 karyawan.

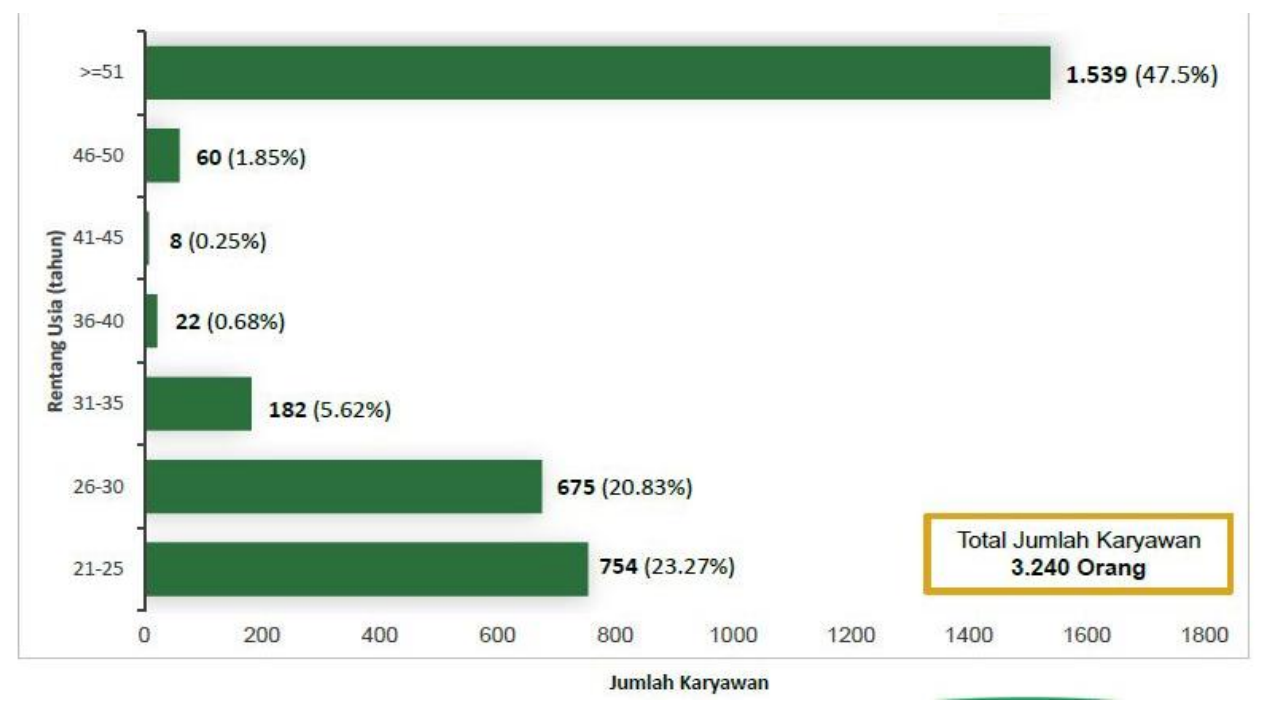

\section{Sumber : PT. Petrokimia Gresik (2018)}

\section{Gambar 1. Grafik Jumlah Karyawan Beradasarkan Usia}

b. Penurunan harga komoditas, harga komoditas internasional yang menurun akan menurunkan biaya pembelian/HPP sehingga subsidi menjadi lebih rendah.

c. Kehandalan pabrik, beberapa peralatan produksi dan fasilitas pendukungnya telah melebihi umur ekonomisnya.

Berdasarkan kondisi perusahaan dan tantangan yang dihadapi, maka perusahaan melakukan perubahan organisasi berdasarkan strategi yang diterapkan yakni terkait Sistem Proses Bisnis, Knowledge Management, dan Program 
Inovasi. Bouckenooghe, Devos dan Broeck (2009) menyatakan bahwa salah satu faktor krusial dalam menentukan implementasi rencana perubahan adalah dengan mempersiapkan karyawan dalam menghadapi perubahan tersebut. Saat karyawan merasa siap untuk berubah, maka organisasi dapat melaksanakan perubahan dan mengurangi tingkat resistensi dari perubahan tersebut.

Peneliti melakukan wawancara terhadap 114 subjek dengan membagi terlebih dahulu sesuai tingkat usia dalam teori Levinson, yakni 17-22 tahun berjumlah 44 Subjek, 23-28 tahun berjumlah 26 Subjek, 29-33 tahun berjumlah 7 Subjek, 34-45 tahun 0 Subjek dan 46-56 tahun berjumlah 41 Subjek. Peneliti mengajukan pertanyaan terkait dengan perubahan yang sedang dilakukan oleh manajemen Perusahaan yakni terkait Perubahan Sistem Proses Bisnis (SAP), Perubahan dan perbaikan media Knowledge Management dan Program Inovasi. Hasil wawancara tersebut menunjukkan kecenderungan bahwa Subjek dengan rentang usia 17-22 tahun tidak tahu terhadap perubahan tersebut, Subjek dengan rentang usia 23-38 tahun cukup tertarik dengan perubahan, Subjek dengan rentang usia 29-33 tahun antusias terhadap perubahan dan siap menjalankan program perubahan, Subjek dengan rentang usia 46-56 tahun mempunyai komitmen yang bagus namun rendah dalam implementasi. Secara umum terhadap perubahan yang sedang dijalankan terdapat respon yang berbeda diantara tingkat usia karyawan.

Holt, Armenakis, Feild dan Harris (2007) mendefinisikan kesiapan individu untuk berubah sebagai sikap komprehensif yang secara simultan dipengaruhi oleh isi (apa yang berubah), proses (bagaimana perubahan diimplementasikan), konteks (lingkungan dimana perubahan terjadi), dan individu (karakteristik individu yang diminta untuk berubah) yang terlibat di dalam suatu perubahan. Kesiapan individu untuk berubah secara kolektif merefleksikan sejauh mana individu atau sekelompok individu cenderung untuk menyetujui, menerima, dan mengadopsi rencana spesifik yang bertujuan untuk mengubah keadaan saat ini.

Holt,dkk.(2007) menyatakan bahwa karyawan yang siap untuk berubah akan percaya bahwa organisasi akan mengalami kemajuan apabila organisasi melakukan perubahan, selain itu mereka memiliki sikap positif terhadap perubahan organisasi dan memiliki keinginan untuk terlibat dalam pelaksanaan perubahan organisasi.Sebaliknya, apabila para karyawan tidak siap untuk berubah, maka mereka tidak akan dapat mengikuti dan merasa kewalahan dengan kecepatan perubahan organisasi yang sedang terjadi.Weiner (2009) menjelaskan bahwa kesiapan organisasi untuk perubahan tidak hanya konstruk bertingkat, tetapi multi-faceted.

Perbedaan Kesiapan Untuk Berubah Karyawan Direktorat Produksi PT. Petrokimia Gresik Ditinjau Dari Usia

Agung Puji Astono dan Idha Rahayuningsih 
Holt, dkk.(2007) mendefinisikan kesiapan individu untuk berubah yang salah satunya dipengaruhi oleh karakteristik individu yang diminta untuk berubah yang terlibat di dalam suatu perubahan.Ketiga,teori Robbins (2017:415) yang menyatakan bahwa, "Perlawanan terhadap perubahan yang bersumber dari individu adalah kebiasaan.Artinya ketika menghadapi perubahan, maka kecenderungan ini akan memberikan taggapan dalam cara-cara yang biasa kita lakukan yang akan menjadi sebuah sumber perlawanan."

Oleh karena itu, terdapat keterikatan langsung antara kesiapan untuk berubah dengan karakteristik individu yang terimplementasikan dalam kebiasaankebiasaan individu tersebut dalam merespon suatu tindakan. Dalam kaitannya dengan karyawan, maka teori perkembangan dari Levinson (1986) yang membagi masa dewasa menjadi 3 fase yaitu fase memasuki dewasa awal, fase puncak dewasa awal, dan fase dewasa tengah juga menampilkan perbedaan karakteristik individu dan kebiasaan atau kecenderungannya.

Pada usia 17-22 tahun. Pada usia ini individu cenderung memiliki hasrat hidup mandiri untuk lepas dari bantuan ekonomi orang tua akan tetapi secara mental, individu belum memiliki tanggung jawab penuh sehingga untuk bisa mewujudkan keinginan tersebut, individu mempersiapkan diri dengan cara menimba ilmu dan keahlian melalui pendidikan formal ataupun pendidikan nonformal. Masa yang kedua yaitu masa memasuki struktur kehidupan dewasa awal yang terjadi pada usia 22-28 tahun. Pada usia ini individu memilih dan menekuni karir sesuai dengan minat-bakat dan kemampuannya akan tetapi terkadang ditemukan adanya ketidakmantapan dalam menekuni pekerjaan, (misalnya, karena faktor penerimaan besarnya gaji, ketidakpuasan kerja) sehingga individu sering mengambil keputusan pindah atau berganti pekerjaan ke tempat lain.

Pada fase ketiga adalah masa usia transisi 30-an yang terjadi pada usia 2845 tahun. Pada usia ini, secara prinsip sama pada masa sebelumnya, yaitu individu masih tetap membangun karir pekerjaan dan membentuk kehidupan keluarga, serta berkarya untuk membangun struktur kehidupan berikutnya. Sedangkan pada fase kedua yakni fase puncak dewasa awal terjadi pada tahun 33-45 tahun, yang terperinci menjadi beberapa tahapan usia yaitu masa puncak kehidupan dewasa awal yang terjadi pada tahun 33-40 tahun. Pada usia ini Individu merasa mantap atau memantapkan diri dengan pilihan pekerjaannya saat ini karena menanggung 
kehidupan keluarga sehingga individu memperkuat komitmen (tekad) untuk membangun karier pekerjaan sedangkan pada masa transisi dewasa menengah, yang terjadi pada usia 40-45 tahun. Pada masa ini, individu telah meniti karier pekerjaan sampai mencapai posisi penting sebagai ahli atau pimpinan (kepala, manajer, direktur). Lalu, pada fase ketiga adalah fase dewasa tengah, yang terjadi pada usia 45-65 tahun. Pada fase ini, individu bertanggung jawab tidak hanya untuk pekerjaan kita sendiri dan mungkin pekerjaan orang lain, tetapi juga untuk pengembangan generasi dewasa muda yang akan segera memasuki generasi dominan. Dari perbedaaan karakteristik dan kebiasaan yang dimunculkan dalam tingkat usia sesuai teori perkembangan Levinson (1986) maka peneliti melihat terdapat keterkaitan antara kesiapan untuk berubah dengan tingkat usia.

\section{TINGKAT USIA}

\section{Kesiapan untuk Berubah}

Indikator menurut Holt, Armenakis, Feild dan Harris (2007) :

1. Individu merasa yakin bahwa perubahan yang diusulkan akan tepat bagi organisasi.

2. Individu merasa yakin bahwa organisasi akan mendapatkan keuntungan dari penerapan perubahan.

3. Karyawan merasa bahwa ia memiliki kemampuan yang berhubungan dengan perubahan yang diusulkan.

4. Karyawan dapat menyelesaikan tugas yang berhubungan dengan perubahan yang diusulkan.

5. Karyawan merasa bahwa pemimpin dan manajemen memiliki komitmen dalam pelaksanaan perubahan yang diusulkan.

6. Karyawan merasa bahwa pemimpin dan manajemen mendukung pelaksanaan perubahan yang diusulkan.

7. Karyawan merasa bahwa ia akan memperoleh manfaat dari perubahan yang diusulkan.

\section{Gambar 2. Kerangka Konseptual}

Perbedaan Kesiapan Untuk Berubah Karyawan Direktorat Produksi PT. Petrokimia Gresik Ditinjau Dari Usia 


\section{Metode Penelitian}

\section{Jenis Penelitian}

Metode penelitian yang digunakan adalah pendekatan kuantitatif, yaitu suatu proses menemukan pengetahuan yang menggunakan data berupa angka sebagai alat menemukan keterangan mengenai apa yang ingin kita ketahui (Margono,2010).Tingkat analisis yang digunakan dalam penelitian adalah komparasi, yaitu penelitian yang diarahkan untuk mengetahui apakah dua atau lebih dari dua kelompok ada perbedaan dalam aspek atau variabel yang diteliti.

\section{Definisi Operasional}

Adalah suatu definisi mengenai variabel yang dirumuskan berdasarkan karakteristik-karakteristik variabel tersebut yang dapat diamati (Azwar,2015). Pada penelitian ini definisi operasional dari variabel dijelaskan sebagai berikut :

1. Kesiapan untuk berubah

Sikap komprehensif yang secara simultan dipengaruhi oleh isi, proses, konteks dan karakteristik individu; merefleksikan sejauh mana individu atau sekelompok individu cenderung untuk menyetujui, menerima, dan mengadopsi rencana spesifik yang bertujuan untuk mengubah keadaan saat ini. Indikator perilaku yang menunjukkan kesiapan untuk berubah menurut pendapat Holt,dkk.(2007) adalah :

a. Karyawan merasa yakin bahwa perubahan yang diusulkan akan tepat bagi organisasi.

b. Individu merasa yakin bahwa organisasi akan mendapatkan keuntungan dari penerapan perubahan.

c. Karyawan merasa bahwa ia memiliki kemampuan yang berhubungan dengan perubahan yang diusulkan.

d. Karyawan dapat menyelesaikan tugas yang berhubungan dengan perubahan yang diusulkan.

e. Karyawan merasa bahwa pemimpin dan manajemen memiliki komitmen dalam pelaksanaan perubahan yang diusulkan.

f. Karyawan merasa bahwa pemimpin dan manajemen mendukung pelaksanaan perubahan yang diusulkan.

g. Karyawan merasa bahwa ia akan memperoleh manfaat dari perubahan yang diusulkan.

Alat ukur yang digunakan adalah skala likert yang dibuat oleh peneliti. Interpretasi hasil pengukuran yaitu semakin tinggi skor hasil pengukuran maka menunjukkan semakin tinggi kesiapan untuk berubah. Sebaliknya, semakin 
rendah skor hasil pengukuran maka menunjukkan semakin rendah kesiapan untuk berubah.

2. Usia

Pada masa dewasa, Levinson (1986) dalam Dariyo (2008) membagi dalam enam kelompok sebagai berikut : Transisi dewasa awal 17-22 tahun, struktur dewasa awal 22-28 tahun, usia transisi 28-33 tahun, puncak dewasa awal 33-40 tahun, transisi dewasa menengah 40-45 tahun, dewasa tengah 45-65 tahun. Berdasarkan teori tersebut, peneliti menyesuaikan dengan kondisi riil usia karyawan di tahun 2018 di mana pada kelompok usia 33-45 tahun hanya berjumlah 5 karyawan dan usia pensiun karyawan adalah 56 tahun. Berdasarkan pertimbangan tersebut Usia dalam penelitian ini dibagi menjadi empat kelompok, yakni usia 17-22 tahun dengan kode (0), usia 23-28 tahun dengan kode (1), usia 29- 33 tahun dengan kode (2) dan usia 45-56 tahun dengan kode (3).

\section{Populasi dan Teknik Pengambilan Sampel}

Populasi adalah seluruh data yang menjadi perhatian dalam suatu ruang lingkup dan waktu yang kita tentukan (Margono,2010). Populasi dalam penelitian ini adalah para karyawan direktorat produksi pupuk PT. Petrokimia Gresik yang berjumlah 948 karyawan,sedangkan sampel adalah bagian dari populasi (Margono, 2010).Teknik pengambilan sampel yang digunakan dalam penelitian adalah sampel proporsional yakni menunjuk pada perbandingan penarikan sampel dari beberapa subpopulasi yang tidak sama jumlahnya. Berdasarkan pendapat dari Sugiyono (2008), dalam penelitian ini digunakan sampel dengan taraf kesalahan 5 $\%$ berdasarkan tabel Krejcie sehingga dari populasi sebesar 948 karyawan, diperoleh sampel sebesar 274 karyawan.

\section{Tabel 2. Populasi dan Sampel}

\begin{tabular}{lll}
\hline Usia & $\begin{array}{l}\text { Jumlah } \\
\text { Populasi }\end{array}$ & Sampel \\
\hline 17-22Th & 199 & 58 \\
\hline $23-28 \mathrm{Th}$ & 302 & 87 \\
\hline 29-33Th & 111 & 31 \\
\hline $33-45 \mathrm{Th}$ & 5 & 2 \\
\hline 46-56Th & 331 & 96 \\
\hline Total & 948 & 274 \\
\hline Tel
\end{tabular}

Teknik Pengumpulan Data

Alat ukur untuk mengukur tingkat kesiapan berubah adalah skala likert. Skala likert adalah sejumlah pertanyaan favorabel dan unfavorabel mengenai suatu objek sikap (Margono, 2010). Uji Validitas menggunakan validitas logik

Perbedaan Kesiapan Untuk Berubah Karyawan Direktorat Produksi PT. Petrokimia Gresik Ditinjau Dari Usia 
yaitu merujuk pada sejauh mana isi tes merupakan representasi dari ciri atribut yang diukur.Kriteria pemilihan item berdasarkan korelasi Product Moment biasanya digunakan batasan rix > 0,30. Semua item yang mencapai koefesien korelasi minimal 0,30 daya pembedanya dianggap memuaskan.Item yang memiliki harga rix $\leq 0,30$ dapat diinterpretasikan sebagai item yang tidak memuaskan (Azwar, 2015). Terdapat 33 item sahih dari 36 item, jadi ada 3 item yang gugur. Item sahih ditujukan dari nilai $r$ yang berkisar antara 0,30-0,95. sedangkan untuk 3 item yang dianggap gugur karena koefisien korelasi kurang dari 0,30. Koefisien reliabilitas alpha Cronbach untuk skala kesiapan berubah sebesar 0,979.Pengujian reliabilitas hasil ukur instrument penelitian dilakukan dengan bantuan SPSS 18.0 for windows dengan operasi analyse > scale > reliability analyse.

\section{Hasil Penelitian dan Pembahasan}

Hasil Uji Asumsi

\section{a. Uji normalitas}

Uji normalitas digunakan untuk mengetahui populasi berdistribusi normal atau tidak. Uji normalitas ini menggunakan Kolmogorov-Smirnov melalui SPSS 18.8 for windows. Berdasarkan hasil uji normalitas satu sampel KolmogorovSmirnovnilai p sebesar 0,000. Nilai tersebut lebih kecil dari tingkat kekeliruan $(0,05)$, maka disimpulkan bahwa data pada penelitian ini memiliki distribusi tidak normal.

Tabel 3. Hasil Uji Normalitas Variabel Kesiapan Untuk Berubah

\begin{tabular}{ccccc}
\hline & & \multicolumn{3}{c}{ Kolmogorov-Smirnov $^{\mathrm{a}}$} \\
\cline { 3 - 5 } & & & & \\
\cline { 3 - 5 } VAR00002 & Statistic & Df & Sig. \\
\cline { 2 - 5 } & 0 & .227 & 58 & .000 \\
\cline { 2 - 5 } & 1 & .343 & 87 & .000 \\
\cline { 2 - 5 } & 2 & .346 & 31 & .000 \\
\hline 3 & .405 & 96 & .000 \\
\hline
\end{tabular}

a. Lilliefors Significance Correction

\section{b. Uji Homogenitas}

Uji homogenitas digunakan untuk mengetahui apakah beberapa varian populasi dari dua atau lebih kelompok data adalah sama atau tidak.Uji homogenitas menggunakan metode Levene's test melalui SPSS 18.8 for windows. Peneliti memakai Uji Levene karena uji tersebut dapat digunakan untuk menguji homogenitas varians pada data yang tidak berdistribusi normal. Nilai uji Levene's 
Test pada tabel 4. ditunjukkan pada baris Nilai Based On Mean, yaitu dengan Sig (p value) 0,001 < 0,05 yang berarti varians keempat kelompok tidak sama atau yang disebut tidak homogen.

\section{Tabel 4.Hasil Uji homogenitas variabel kesiapan untuk berubah}

\begin{tabular}{|c|c|c|c|c|c|}
\hline & & Levene Statistic & df1 & df2 & Sig. \\
\hline \multirow[t]{4}{*}{ VAR00001 } & Based on Mean & 11.455 & 1 & 269 & .001 \\
\hline & Based on Median & 3.416 & 1 & 269 & .066 \\
\hline & $\begin{array}{l}\text { Based on Median and with } \\
\text { adjusted df }\end{array}$ & 3.416 & 1 & 261.224 & .066 \\
\hline & Based on trimmed mean & 15.992 & 1 & 269 & .000 \\
\hline
\end{tabular}

\section{c. Uji Hipotesis}

Hasil uji normalitas tidak terpenuhi, uji homogenitas juga tidak terpenuhi dan data berasal dari 4 kelompok usia, maka peneliti menggunakan uji hipotesis Kruskall Wallis. Nilai p value ditunjukkan oleh nilai Asymp.Sig yaitu apabila nilainya < batas kristis 0,05 maka dapat ditarik kesimpulan statistik terhadap hipotesis yang diajukan diterima yaitu ada perbedaan yang signifikan kesiapan untuk berubah karyawan direktorat produksi PT. Petrokimia Gresik ditinjau dari usia.

Perbedaan kesiapan untuk berubah tiap kelompok maka ada uji lanjutan yakni dengan uji Mann Whitney U. Hasil uji ini menunjukkan mean rank rerata peringkat yang berbeda sebagaimana yang terdapat pada tabel 5. antara kelompok usia 17-22 tahun $(0)=40,26$; kelompok usia 23-28 tahun $(1)=115,00$; kelompok usia 29-33 tahun = 221,39 (2); dan kelompok usia 45-56 tahun $(3)=186,72$ sehingga dapat disimpulkan bahwa perbedaan kesiapan berubah dari keempat kelompok tersebut adalah signifikan.

\section{Tabel 5. Perbedaan Rerata Peringkat Tiap Kelompok}

\begin{tabular}{lll}
\hline No. & Kategori Usia / Kode & \multicolumn{1}{c}{ Rata-Rata } \\
\hline 1. & $17-22$ tahun / 0 & 40,26 \\
2. & $23-28$ tahun / 1 & 115 \\
3. & $29-33$ tahun / 2 & 221,39 \\
4. & 45-56 tahun / 3 & 186,72 \\
\hline
\end{tabular}

Berdasarkan tabel 6. dapat dilihat bahwa ada 15 resonden dengan tingkat kesiapan untuk berubah yang tinggi dengan prosentase $5,51 \%$, sedangkan responden dengan tingkat kesiapan untuk berubah yang sedang berjumlah 188 orang dengan prosentase $69,12 \%$, kemudian responden dengan tingkat kesiapan

Perbedaan Kesiapan Untuk Berubah Karyawan Direktorat Produksi PT. Petrokimia Gresik Ditinjau Dari Usia Agung Puji Astono dan Idha Rahayuningsih 
untuk berubah yang rendah berjumlah 69 orang dengan prosentase sebesar 25,37 $\%$.

\section{Tabel 6. Prosentase Tingkat Kesiapan Untuk Berubah}

\begin{tabular}{lccc}
\hline \multicolumn{1}{c}{ Variabel } & \multicolumn{3}{c}{ Kategori dan Kriteria } \\
\hline $\begin{array}{l}\text { Kesiapan } \\
\text { untuk }\end{array}$ & Tinggi & Sedang & Rendah \\
Berubah & $\mathrm{T}>50+(0.5) .10$ & $50-(0.5) .10 \leq \mathrm{T} \leq 50+$ & $\mathrm{T}>50-(0.5) .10 \mathrm{~T}<$ \\
& $\mathrm{T}>55$ & $(0.5) .10 \quad 45 \leq \mathrm{T} \leq 55$ & 45 \\
\cline { 2 - 4 } & 15 orang & 188 orang & 69 orang \\
& $5,51 \%$ & $69,12 \%$ & $25,37 \%$ \\
\hline
\end{tabular}

Pada Tabel 7. aitem kesiapan untuk berubah yang cenderung paling banyak dipilih responden yaitu item nomor 15, 29 dengan prosentase sama yaitu 80,5\%, item nomor 15 yaitu "Saya senang proses produksi menjadi lebih efektif dan efisien dengan adanya inovasi". Sedangkan item nomor 29 yaitu "Saya yakin program Konvensi Inovasi akan menghasilkan penghematan keuangan Perusahaan". Diikuti dengan item nomor 27 yaitu "Saya bangga dengan diberikannya fasilitas sarana dan prasarana untuk share knowledge oleh Manajemen" dengan prosentase 73,9\%.

Data tersebut menunjukkan bahwa kesiapan untuk berubah dimulai dari karyawan merasa bahwa ia akan memperoleh manfaat dari perubahan yang diusulkan dan individu merasa yakin bahwa organisasi akan mendapatkan keuntungan dari penerapan perubahan dan ditindaklanjuti dengan upaya nyata bahwa pemimpin dan manajemen mendukung pelaksanaan perubahan yang diusulkan tersebut.

Berikut ini disajikan tabel 7.sebaran sikap dan perilaku yang menunjukkan kesiapan untuk berubah. 
Tabel 7. Item Kesiapan untuk Berubah yang Banyak Dipilih Responden

\begin{tabular}{|c|c|c|c|c|c|}
\hline \multirow[t]{2}{*}{ Indikator } & \multirow{2}{*}{$\begin{array}{c}\text { No } \\
\text { Aitem }\end{array}$} & \multirow[t]{2}{*}{ Pernyataan } & \multicolumn{2}{|c|}{$\begin{array}{c}\text { Prosentase Pilihan } \\
\text { Jawaban }\end{array}$} & \multirow[t]{2}{*}{ Total } \\
\hline & & & 4 & 5 & \\
\hline $\begin{array}{l}\text { Karyawan merasa } \\
\text { bahwa ia akan } \\
\text { memperoleh manfaat } \\
\text { dari perubahan yang } \\
\text { diusulkan (Personal } \\
\text { benefit) }\end{array}$ & 15 & $\begin{array}{l}\text { Saya senang proses } \\
\text { produksi menjadi lebih } \\
\text { efektif dan efisien } \\
\text { dengan adanya inovasi }\end{array}$ & $38,6 \%$ & $41,9 \%$ & $80,5 \%$ \\
\hline $\begin{array}{l}\text { Individu merasa yakin } \\
\text { bahwa organisasi } \\
\text { akan mendapatkan } \\
\text { keuntungan dari } \\
\text { penerapan perubahan } \\
\text { (Appropriatness) }\end{array}$ & 29 & $\begin{array}{l}\text { Saya yakin program } \\
\text { Konvensi Inovasi akan } \\
\text { menghasilkan } \\
\text { penghematan keuangan } \\
\text { Perusahaan }\end{array}$ & $60,3 \%$ & $20,2 \%$ & $80,5 \%$ \\
\hline $\begin{array}{l}\text { Karyawan merasa } \\
\text { bahwa pemimpin dan } \\
\text { manajemen } \\
\text { mendukung } \\
\text { pelaksanaan } \\
\text { perubahan yang } \\
\text { diusulkan } \\
\text { (Management } \\
\text { Support) }\end{array}$ & 27 & $\begin{array}{l}\text { Saya bangga dengan } \\
\text { diberikannya fasilitas } \\
\text { sarana dan prasarana } \\
\text { untuk share knowledge } \\
\text { oleh Manajemen }\end{array}$ & $37,5 \%$ & $36,4 \%$ & $73,9 \%$ \\
\hline
\end{tabular}

Hasil ini sejalan dengan pandangan Armenakis dan Harris (2009) faktor utama yang dapat merubah keyakinan diri karyawan untuk mendukung perubahan yaitu: Pertama, Principal support yaitu persepsi bahwa organisasi memberikan dukungan dan berkomitmen dalam pelaksanaan perubahan dan mensukseskan perubahan organisasi. Kedua, Personal valance yaitu keyakinan bahwa perubahan akan memberikan keuntungan personal bagi karyawan. Adanya keyakinan diatas tidak semata-mata hanya mempengaruhi kesiapan untuk berubah namun juga mempengaruhi bagaimana karyawan akan mengadopsi dan berkomitmen terhadap perubahan organisasi.

Pada tabel 8. terlihat bahwa item kesiapan untuk berubah yang paling sedikit dipilih oleh responden antara lain : item nomor 21 dengan prosentase 41,9\%, yaitu "Saya mampu melakukan inovasi di area kerja yang menjadi tanggung jawab saya". Diikuti dengan item nomor 7 dengan prosentase $25,7 \%$ yaitu "Saya yakin perubahan sistem ke SAP (System Application and Product in data Processing) akan meningkatkan keuntungan Perusahaan". Kemudian item nomor 25 dengan prosentase 16,2\% yaitu "Saya yakin perubahan sistem SAP akan berlangsung lancar dengan ditunjuknya Fasilitator tiap bagian oleh Manajemen".

Perbedaan Kesiapan Untuk Berubah Karyawan Direktorat Produksi PT. Petrokimia Gresik Ditinjau Dari Usia 
Tabel 8. Item Kesiapan Untuk Berubah Yang Sedikit Dipilih Responden

\begin{tabular}{|c|c|c|c|c|c|}
\hline \multirow[t]{2}{*}{ Indikator } & \multirow[t]{2}{*}{ No Item } & \multirow[t]{2}{*}{ Pernyataan } & \multicolumn{2}{|c|}{$\begin{array}{c}\text { Prosentase Pilihan } \\
\text { Jawaban }\end{array}$} & \multirow[t]{2}{*}{ Total } \\
\hline & & & 4 & 5 & \\
\hline $\begin{array}{l}\text { Karyawan merasa } \\
\text { bahwa ia memiliki } \\
\text { kemampuan dapat } \\
\text { menyelesaikan tugas } \\
\text { yang berhubungan } \\
\text { dengan perubahan } \\
\text { yang diusulkan } \\
\text { (Change Efficiacy) } \\
\end{array}$ & 21 & $\begin{array}{l}\text { Saya mampu } \\
\text { melakukan inovasi di } \\
\text { Area kerja yang } \\
\text { menjadi tanggung } \\
\text { jawab saya }\end{array}$ & $41,9 \%$ & $0 \%$ & $41,9 \%$ \\
\hline $\begin{array}{l}\text { Individu merasa } \\
\text { yakin bahwa } \\
\text { organisasi akan } \\
\text { mendapatkan } \\
\text { keuntungan dari } \\
\text { penerapan perubahan } \\
\text { (Appropriateness) }\end{array}$ & 7 & $\begin{array}{l}\text { Saya yakin perubahan } \\
\text { sistem ke SAP } \\
\text { (System Application } \\
\text { and Product in data } \\
\text { Processing) akan } \\
\text { meningkatkan } \\
\text { keuntungan } \\
\text { Perusahaan }\end{array}$ & $25,7 \%$ & $0 \%$ & $25,7 \%$ \\
\hline $\begin{array}{l}\text { Karyawan merasa } \\
\text { bahwa pemimpin } \\
\text { dan manajemen } \\
\text { mendukung } \\
\text { pelaksanaan } \\
\text { perubahan yang } \\
\text { diusulkan } \\
\text { (Management } \\
\text { Support) }\end{array}$ & 25 & $\begin{array}{l}\text { Saya yakin perubahan } \\
\text { sistem SAP akan } \\
\text { berlangsung lancar } \\
\text { dengan ditunjuknya } \\
\text { Fasilitator tiap bagian } \\
\text { oleh Manajemen }\end{array}$ & $16,2 \%$ & $0 \%$ & $16,2 \%$ \\
\hline
\end{tabular}

Data tersebut menunjukkan bahwa banyak diantara karyawan yang berusia 17-22 tahun tidak mampu melakukan inovasi di unit kerja produksinya. Hasil observasi dan wawancara yang peneliti lakukan hal tersebut dikarenakan banyak unit produksi yang sudah berusia tua dan kecil kemungkinan untuk mengefisienkan unit tersebut sehingga inovasi juga sulit ditemukan. Selain itu, juga ada ketidakyakinan bahwa penerapan SAP akan meningkatkan keuntungan perusahaan, karena sistem yang lama masih bisa digunakan dan SAP membutuhkan biaya yang tidak sedikit. Hal lain yang bisa disimpulkan dari data diatas adalah keresahan dalam penerapan SAP di unit produksi, meski ada fasilitator di tingkat bagian, namun beradaptasi dengan sistem yang baru bukanlah hal yang mudah.

Hasil ini sejalan dengan teori perkembangan Levinson (1986) yang membagi masa dewasa menjadi enam kelompok usia, dimana kelompok usia 1722 tahun adalah transisi dewasa dengan karakteristik secara fisik, bentuk tubuhnya tampak seperti orang dewasa lainnya, tetapi secara mental, individu belum 
memiliki tanggung jawab penuh karena masih hidup bergantung secara ekonomi dari orang tuanya.

\section{Kesimpulan dan Saran Kesimpulan}

Berdasarkan hasil penelitian, hasil uji hipotesis Kruskall Wallis $=0,000$ lebih kecil dari batas kritis 0,05. Hasil tersebut dapat disimpulkan bahwa terdapat perbedaan tingkat kesiapan untuk berubah karyawan ditinjau dari usia. Hasil uji Mann Whitney $U$ menunjukkan mean rank rerata peringkat yang berbeda antar tingkat usia. Pada tingkat usia dengan kode $0=40,26$, tingkat usia dengan kode 1 $=115,00$, tingkat usia dengan kode $2=221,39$ dan tingkat usia dengan kode $3=$ 186,72. Kesiapan untuk berubah yang paling rendah terdapat pada kelompok tingkat usia dengan kode 0 dan kesiapan untuk berubah yang paling tinggi terdapat pada kelompok usia 29- 33 tahun kode (2).

\section{Saran}

Saran yang diberikan dari penelitian ini berdasarkan pada hasil pembahasan sebagai berikut :

\section{Bagi Perusahaan}

a. Bagi perusahaan adalah secara terus-menerus dan berkesinambungan memberikan pelatihan inovasi terutama bagi karyawan dengan kelompok usia dewasa awal yakni usia 17-33 tahun. Pelatihan inovasi tidak hanya bermuara pada peningkatan produksi pabrik karena rata-rata usia pabrik sudah melebihi nilai ekonomisnya sehingga pelatihan inovasi juga diperlukan untuk mengurangi keborosan bahan baku, meminimalkan limbah dan meningkatkan safety.

b. Manajemen perusahaan perlu memberikan bimbingan terhadap penerapan SAP secara berkesinambungan, terutama pada kelompok karyawan dengan usia dewasa awal 17-22 tahun dan kelompok usia dewasa tengah 45-56 tahun yang memang kesulitan dalam beradaPT.asi dengan sistem yang baru. Hal ini perlu dilakukan agar tidak terjadi saling melempar tanggung jawab terhadap job load masing-masing.

c. Manajemen perusahaan juga perlu untuk memberlakukan SAP dengan benar dan jujur, agar karyawan merasa yakin bahwa manajemen memberikan dukungan penuh terhadap perubahan di perusahaan utamanya terkait dengan transparansi pengadaan barang dan biaya keuangan lainnya. Termasuk mou yang memberatkan keuangan perusahaan harus diselesaikan dengan baik.

\section{Bagi karyawan}

Perbedaan Kesiapan Untuk Berubah Karyawan Direktorat Produksi PT. Petrokimia Gresik Ditinjau Dari Usia 
Manfaat bagi karyawan yaitu dapat memperbaiki skill dan melakukan sinergi dengan karyawan unit lain yang terlibat langsung dalam proses perubahan, sehingga perubahan berjalan dengan lebih baik sesuai tujuan perusahaan.

\section{Bagi Peneliti Selanjutnya}

a. Bagi peneliti selanjutnya yang ingin melakukan penelitian lebih lanjut mengenai kesiapan untuk berubah, diharapkan untuk menambah referensi teori dengan proses assesmen yang lebih merata kepada populasi yang jumlahnya besar sehingga mendapatkan data yang lebih akurat.

b. Peneliti selanjutnya yang tertarik untuk meneliti kesiapan untuk berubah agar mempertimbangkan faktor-faktor lain yang masih belum dibatasi dalam penelitian ini.

\section{Daftar Pustaka}

Azwar. (2015). Reliabilitas dan Validitas. Edisi 4. Yogyakarta : Pustaka Pelajar. Bouckenooghe, D., Devos, G., \& Broeck, H. D. (2009). Organizational Change Questionnaire-Climate of Change, Process, and Readiness: Development of a New Instrument. The Journal of Psychology, 143 (6), 559.

Dariyo, A. (2004). Psikologi Perkembangan Dewasa Muda. Jakarta: Grasindo

Holt, D.T., Armenakis,A.A., Feild, H.S \& Harris, S.G. (2007). Readiness for Organizational Change: The Systematic Development of a Scale. The Journal of Applied Behavioral Science, 43 (2), 232-255.

Levinson, D. (1986). A ConcePT.ion of Adult Development. American Psychologist, 41.

Margono. (2010). Metodologi Penelitian Pendidikan. Jakarta: Rineka Cipta. (2018).Petrokimia. Profil Perusahaan.

Sugiyono, (2008). Metode Penelitian Kunatitatif Kualitatif dan R\&D. Bandung Alfabeta.

Robbins, S.P. \& Judge. (2017). Perilaku Organisasi. Edisi Keenambelas. Salemba Empat: Jakarta.

Weiner, B.(2009). A Theory of Organizational Readiness for Change. Department of Health Policy and Management, Gillings School of Global Public Health, University of North Carolina Chapel Hill, Chapel Hill, North Carolina, USA. 